\title{
THE ECOLOGY, DISTRIBUTION AND TAXONOMY OF THE CENTIPEDES FOUND ON THE SHORE IN THE PLYMOUTH AREA
}

\author{
By J. G. E. Lewis \\ Department of Biological Sciences, Bradford Institute of Technology, \\ Bradford, 7, Yorkshire ${ }^{1}$
}

(Text-figs. I and 2)

The Plymouth Marine Fauna (Marine Biological Association, 1957) lists only one species of the class Chilopoda (centipedes) as occurring on the shore in the Plymouth area. This species is Scolioplanes maritimus (Leach), reported as occurring under stones on the shore at Plymouth (Parfitt, I866), and regularly in crevices in the upper half of the tidal zone at Church Reef, Wembury Bay (Morton, 1954).

This paper describes the distribution of six species of centipedes collected from the littoral zone between Wembury Bay to the east of Plymouth and Cawsand Bay to the west. Information is also given about their ecology and taxonomy. All the species found are members of the order Geophilomorpha.

\section{FAMILY SCHENDYLIDAE}

\section{Hydroschendyla submarina (Grübe)}

Regarded as uncommon in the British Isles, this species has been recorded from Jersey (D'Arcy Thompson, I889), Cornwall (Pocock, I899; Jackson, I916), and more recently from Yorkshire (Cloudsley-Thompson, I948) and Pembrokeshire (Bassindale \& Barrett, I957).

At Plymouth, Hydroschendyla is common in rock crevices between the Verrucaria and Fucus serratus zones in which there is a heavy deposit of silt.

Localities include Cawsand Bay (20. iv. 60, 8. viii. 60), Tinside (25. vi. 59), Fisher's Nose (25. vi. 59), Wembury Reef, mid region (1959, Aug. I960), and Wembury West Reef (26. vi. 59, I. viii. 60). At the above localities the species was found in rock crevices only: two specimens were taken from the main beach at Wembury at HWN by Prof. G. E. Newell (8. viii. 48).

At Wembury, nine females were found brooding eggs in crevices in the mid Chthamalus zone (22. vi. 59), and one female was found brooding foetus-stage larvae in the Verrucaria zone at Tinside (26. vi. 59). Eight newly moulted

\footnotetext{
1 Present address: Zoology Department, University of Khartoum, Khartoum, Sudan.
} 
animals were found at Wembury (18. vi. 59), two were found at Fisher's Nose (25. vi. 59) and five at Cawsand (2. viii. 60 and 8. viii. 60). All the moulting and brooding specimens were taken between MHWS and EHWN where they are subject to regular tidal immersion. In this respect Hydroschendyla differs from Strigamia (= Scolioplanes) maritima, which has been studied at Cuckmere Haven (Lewis, I96I $a$ ) and Plymouth (see below). Strigamia migrates to the top of the shore above the HWM of summer tides to moult and lay its eggs. The latter are very permeable and shrink rapidly in unsaturated air and sea water. The eggs of Hydroschendyla are, however, impermeable, showing no change in volume as measured with an eye-piece graticule after $\mathrm{I} 2 \mathrm{~h}$ in sea water, or the same period of time in unsaturated air. Presumably the water-proofing mechanism developed in Hydroschendyla eggs renders unnecessary the breeding migration to the top of the shore characteristic of Strigamia, and the absence of an upshore migration by animals about to moult suggests that they are capable of withstanding immersion.

\section{TABLE 1. THE MAIN CHARACTERS OF TEN HYDROSCHENDYLA SUBMARINA FROM PLYMOUTH}

The three numbers in the column under 'clypeal hairs' represent the numbers of hairs in each of three transverse rows; the most anterior row is given first. The numbers of prehensorial teeth and coxal glands are given for both right and left sides.

\begin{tabular}{|c|c|c|c|c|c|c|c|}
\hline Number & Sex & $\begin{array}{l}\text { Length } \\
\text { (mm) }\end{array}$ & $\begin{array}{c}\text { Pediferous } \\
\text { segments }\end{array}$ & $\begin{array}{c}\text { Clypeal } \\
\text { hairs }\end{array}$ & $\begin{array}{c}\text { Labral } \\
\text { teeth }\end{array}$ & $\begin{array}{l}\text { Prehensorial } \\
\text { teeth }\end{array}$ & $\begin{array}{l}\text { Coxal } \\
\text { glands }\end{array}$ \\
\hline \multicolumn{8}{|c|}{ Cawsand specimens } \\
\hline I & 우 & $22 \cdot 5$ & 49 & $2+2+2$ & 4 & Nil & $2-2$ \\
\hline 2 & 우 & $12 \cdot 5$ & 49 & $2+2+2$ & 4 & $2-0$ & $I-I$ \\
\hline 3 & 우 & 23.5 & 49 & $2+2+2$ & 4 & Nil & $2-2$ \\
\hline 4 & 우 & 20.5 & 49 & $2+2+2$ & 6 & Nil & $2-2$ \\
\hline 5 & 우 & 20.5 & 51 & $2+2+2$ & 4 & $I-4$ & $2-2$ \\
\hline \multicolumn{8}{|c|}{ Wembury specimens } \\
\hline 6 & $\hat{0}$ & $28 \cdot 0$ & 47 & $2+2+2$ & 7 & Nil & $2-2$ \\
\hline 7 & 우 & I6.5 & 49 & $2+2+2$ & 3 & Nil & $I-I$ \\
\hline 8 & 우 & 23.5 & 49 & $2+2+3$ & 5 & $3-4$ & $2-2$ \\
\hline 9 & 우 & 36.0 & 47 & $2+4+2$ & 7 & $4-5$ & $2-2$ \\
\hline IO & 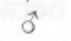 & 17.5 & 49 & $2+2+2$ & 5 & $\mathrm{Nil}$ & $2-2$ \\
\hline
\end{tabular}

The main characters of ten Hydroschendyla from Plymouth are given in Table I. They correspond exactly with Brölemann's (I930) description of French specimens, with the exception of the structure of the inner edge of the prehensor (poison claw) which he describes as having a crenulated edge formed by scattered incisions, but which in six of the ten Plymouth specimens examined was smooth. As a result these specimens run down to Brachyschendyla montana (Attems) in Brölemann's key. Such specimens may easily be distinguished from the latter species by the structure of the last pair of legs, the last segment being at least as long as the penultimate in Brachy- 
schendyla but four times shorter in Hydroschendyla. Obviously the crenulation of the inner edge of the poison claw can no longer be used as a key character to separate Hydroschendyla from other schendylids.

With the exception of Cloudsley-Thompson's record of the species from Yorkshire, Hydroschendyla has a south-western distribution. Dr W. Ballantine has sent me a number of littoral centipedes from Dale Fort, Pembrokeshire; they are all Strigamia maritima. He could not trace the original specimens of the Hydroschendyla submarina of Bassindale \& Barrett's (I957) list, and it seems possible that the specimens were in fact Strigamia maritima.

Schendyla peyerimhoffi Bröl. \& Rib.

Described as new to Great Britain (Lewis, $196 \mathrm{I} b$ ), one of the specimens was taken at Queen Anne's Battery, Coxide, Plymouth, from a loam-filled crevice in the lower Xanthoria zone (June, 1959). The other specimens were taken at Cuckmere Haven, Sussex.

\section{FAMILY GEOPHILIDAE}

Strigamia ( = Scolioplanes) maritima (Leach)

This is undoubtedly the most common British littoral centipede and is the one listed in the Plymouth Marine Fauna. It has been reported from a large number of localities around the British Isles (Cloudsley-Thompson, I948, I95I).

In the Plymouth area it is common in rock crevices in the Xanthoria and Verrucaria zones and in the top of the Chthamalus zone. Morton(1954) reports finding it down to MTL at Church Reef, Wembury; but in my experience it is replaced in the Chthamalus zone by Hydroschendyla submarina, and probably Morton was dealing with two species.

Localities include Cawsand Bay (2. viii. 60), Tinside (26. vi. 59), Fisher's Nose (25. vi. 59), Dunstone Point (5. iv. 60), Wembury West Reef (26. vi. 59) and mid region (I8. vi. 59). The above records are from rock crevices; the

TABLE 2. THE COMPOSITION OF TWO SAMPLES OF THE STRIGAMIA MARITIMA POPULATION AT JENNYCLIFF BAY, 15 JUNE 1959

A, Sample from drift between EHws and MHWs; B, sample from the storm line.

$\begin{array}{lcccc} & \begin{array}{c}\text { Adolescens } \\ \text { I and II }\end{array} & \begin{array}{c}\text { Adolescens } \\ \text { III }\end{array} & \overbrace{\text { Males }}^{\text {Maturus }} & \text { Females } \\ \text { Sample A } & 7 & 27 & 0 & 0 \\ \text { Sample B } & \text { I0 } & 9 & 28 & \text { I8 }\end{array}$

species was abundant in shingle and the underlying rock crevices in a small cove at the northern end of Jennycliff Bay (June 1959, Apr., July and Aug. 1960, Aug. 196r). 
As Strigamia was so abundant at Jennycliff, an attempt was made to compare its way of life there with that of the population at Cuckmere Haven, Sussex, already worked out (Lewis, I96I $a$ ).

The Jennycliff population was found to be aggregated in two regions, at the storm line, and at MHWs some 4-5 ft. vertically lower down the shore. All the 25 specimens found moulting in the field, or which moulted in the laboratory after collection, were taken from the upper region, suggesting that pre-moult animals migrate out of the summer tidal zone at Plymouth as they do at Cuckmere. On I6 June 1959, I2 females were found brooding clutches of eggs in grit and decaying organic matter between flat rocks at the storm line at a depth of $\mathrm{I} \mathrm{ft.} 3$ in. At this time mature males were found only in this region and were absent from the drift line of recent tides farther down the shore, though immature specimens were abundant there(Table 2). Apparently, as at Cuckmere, gravid females migrate to the top of the shore before laying their eggs and the males follow them, probably to deposit their spermatophores.

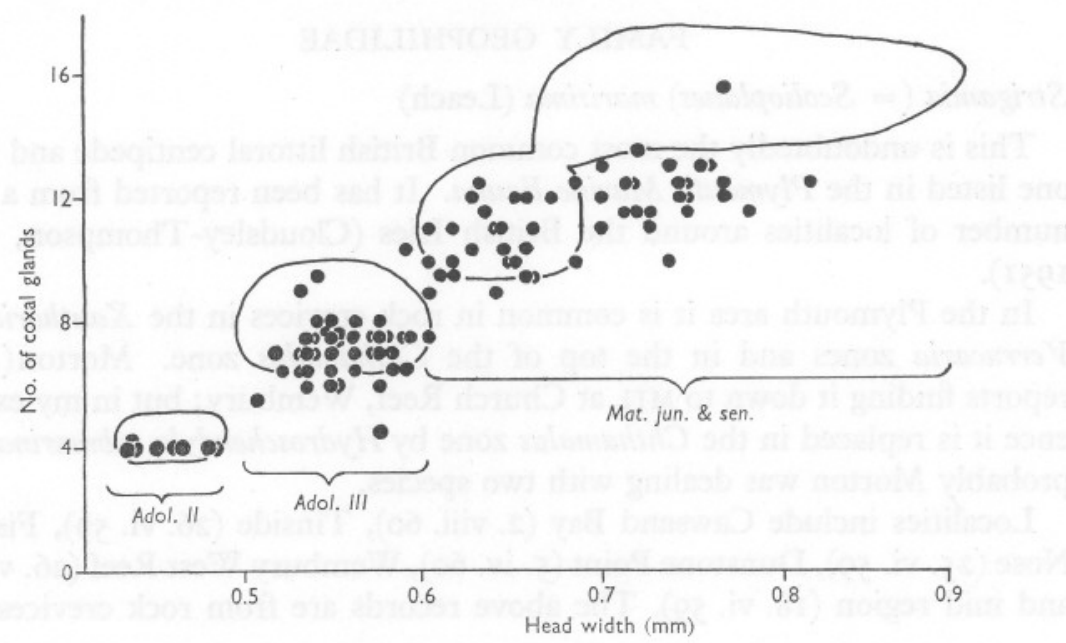

Fig. I. Plot of the average number of coxal glands against head width of individuals of the last four post-embryonic stadia of female Strigamia maritima from Jennycliff Bay, Plymouth (black circles). The continuous line delimits the values obtained for these stadia at Cuckmere Haven.

The Cuckmere and Jennycliff populations were found to differ in certain quantitative characters. In females from Cuckmere, five post-embryonic stadia were distinguished when head width was graphed against the average of the number of gland-pores opening on the coxae of the last pair of legs. In females from Jennycliff only four post-embryonic stadia are distinguishable, though the large spread of the last group suggests that it may contain females belonging to more than one year-group (Fig. I). The difference 
between the two populations could be accounted for by supposing that few if any coxal glands are added at the moult from the fourth to the fifth postembryonic stage (maturus junior to maturus senior) in the Jennycliff population.

The populations again differ in the leg numbers found in both males and females (Table 3). Data are also given for a population at Dale Fort, Pembrokeshire, collected for me by Dr Ballantine, and for one from Polperro, Cornwall (specimens in the British Museum, Natural History). The observed variation probably represents genetic differences between the discontinuous populations of this species.

TABLE 3. PERCENTAGE COMPOSITION OF SAMPLES OF STRIGAMIA MARITIMA FROM DIFFERENT LOCALITIES WITH REGARD TO THE NUMBER OF PAIRS OF LEGS

\begin{tabular}{|c|c|c|c|c|c|c|c|c|c|c|c|c|}
\hline \multirow[b]{3}{*}{ Locality } & \multicolumn{6}{|c|}{ Males } & \multicolumn{6}{|c|}{ Females } \\
\hline & \multirow{2}{*}{$\begin{array}{l}\text { No. in } \\
\text { sample }\end{array}$} & \multicolumn{5}{|c|}{$\begin{array}{l}\% \text { of individuals with par- } \\
\text { ticular no. of leg pairs }\end{array}$} & \multirow{2}{*}{$\begin{array}{l}\text { No. in } \\
\text { sample }\end{array}$} & \multicolumn{5}{|c|}{$\begin{array}{l}\% \text { of individuals with parti- } \\
\text { cular no. of leg pairs }\end{array}$} \\
\hline & & 43 & 45 & 47 & 49 & $5 \mathrm{I}$ & & 43 & 45 & 47 & 49 & $5 \mathrm{I}$ \\
\hline $\begin{array}{l}\text { Cuckmere } \\
\text { Haven }\end{array}$ & $5 \mathrm{I}$ & 2 & 4 & 62 & 34 & o & II 8 & 0 & 0 & 7 & 55 & 38 \\
\hline Plymouth & 22 & 0 & 0 & 36 & 63 & 0 & 34 & 0 & 0 & 0 & 20 & 80 \\
\hline Polperro & 13 & 0 & 0 & 100 & 0 & 0 & II & 0 & 0 & 0 & 9I & 9 \\
\hline Dale Fort & 17 & 0 & 0 & 88 & 12 & 0 & 12 & 0 & 0 & 0 & 83 & 17 \\
\hline
\end{tabular}

Field observations on the prey of S. maritima have been reviewed by Lewis (I96I $a$ ). It was concluded that the species is a non-specific carnivore. At Jennycliff the species was observed feeding on Orchestia gammarella (Pallas) on six occasions, once on a large Ligia oceanica, and once on a small dipteran; the above observations were made in the daytime.

\section{Clinopodes linearis (C. L. Koch)}

One specimen, length $32.0 \mathrm{~mm}$ with 73 pairs of legs, was collected by Prof. G. E. Newell on the beach at Wembury Bay at HWM (8. viii. 48). A terrestrial species, it has previously been reported only from Cornwall and the north of England (Blower, 1955a).

\section{Necrophloeophagus longicornis (Leach)}

This species, which is common in arable land and grassland (Blower, I955a), has previously been reported twice from the sea shore in Britain. Pocock (1903) took it beneath Zostera on the beach at West Mersea, Essex, and Eason (I957) found specimens in shingle between tide-marks associated with Strigamia maritima on the Menai Straits near Caernarvon. Prof. Newell found eight specimens on the beach at Wembury Bay (8. viii. 48), and I have seven 
specimens taken from the shingle bank and salt marsh at Cuckmere Haven during 1957 and 1958 . It is possible that this species will prove to be common on British shores; whether or not it breeds in the littoral zone remains to be discovered.

\section{Geophilus fucorum seurati Brölemann}

This subspecies has recently been described as new to Great Britain (Blower, I96I). The specimens were taken at Llandudno, Caern., and Port St Mary, Isle of Man.

\section{TABLE 4. THE MAIN CHARACTERS OF FOURTEEN GEOPHILUS FUCORUM SEURATI FROM SOUTHERN ENGLAND}

N.B. The number of labral teeth is shown as the number of central tubercular teeth, with the number of slender flanking teeth shown on each side.

\begin{tabular}{|c|c|c|c|c|c|c|}
\hline No. & Sex & $\begin{array}{l}\text { Length } \\
(\mathrm{mm})\end{array}$ & $\begin{array}{l}\text { Pediferous } \\
\text { segments }\end{array}$ & $\begin{array}{c}\text { Labral } \\
\text { teeth }\end{array}$ & $\begin{array}{c}\text { Prehensorial } \\
\text { teeth }\end{array}$ & $\begin{array}{l}\text { Coxal } \\
\text { glands }\end{array}$ \\
\hline \multicolumn{7}{|c|}{ Whitstable specimen } \\
\hline $\mathbf{I}$ & 우 & $23 \cdot 0$ & 57 & - & II -12 & $4-4$ \\
\hline \multicolumn{7}{|c|}{ Cuckmere specimens } \\
\hline 2 & $\hat{0}$ & $24 \cdot 0$ & 53 & - & $7-7$ & $3-3$ \\
\hline 3 & 0 & $27 \cdot 5$ & 53 & 一 & I5-I5 & $4-4$ \\
\hline 4 & 0 & 20.5 & 53 & - & 10-10 & $3-2$ \\
\hline 5 & 우 & $3 \mathrm{I} \cdot 0$ & 57 & - & -13 & $4-4$ \\
\hline 6 & ô & 19.5 & 53 & 一 & $7-9$ & $3-3$ \\
\hline \multicolumn{7}{|c|}{ Jennycliff specimens } \\
\hline 7 & 우 & $21 \cdot 5$ & 57 & - & $8-9$ & $4-4$ \\
\hline 8 & 우 & $28 \cdot 0$ & 57 & $0+3+0$ & $12-13$ & $4-4$ \\
\hline 9 & 우 & $22 \cdot 0$ & 57 & - & $2-9$ & $4-3$ \\
\hline Io & 우 & $24 \cdot 0$ & 57 & - & $13-12$ & $5-5$ \\
\hline II & 우 & $28 \cdot 0$ & 57 & - & I3-I4 & $4-5$ \\
\hline 12 & 우 & $24 \cdot 0$ & 57 & $I+2+I$ & II-IO & $4-4$ \\
\hline \multicolumn{7}{|c|}{ Wembury specimens } \\
\hline 13 & 0 & $33 \cdot 0$ & 53 & $I+3+I$ & $13-15$ & $3-3$ \\
\hline I4 & 우 & 18.5 & 57 & $\mathrm{I}+3+\mathrm{I}$ & $7-8$ & $3-3$ \\
\hline
\end{tabular}

At Plymouth, six specimens of G. fucorum seurati were taken from shingle and rock crevices at the storm line with Strigamia maritima at Jennycliff Bay (I6. vi. 59, I3. iv. 60 and I4. vi. 60) and two from crevices in the Verrucaria and upper Chthamalus zone at Wembury West Reef (I4. iv. 60). Elsewhere on the south coast, two specimens were taken from shingle at the edge of the salt marsh, and three from the berm of the shingle bank at Cuckmere Haven (1957-59), and one from sandy gravel just below MHWN at Whitstable, Kent. The latter was collected by Dr A. J. Joyner. The main characters of these specimens are summarized in Table 4. 
The south-coast specimens are of interest in that some of them differ from those described from north-west coasts by Blower in characters which are used to separate G. fucorum Bröl. from the closely allied G. algarum Bröl. In north-western specimens the labrum bears 4 tubercular teeth, in southern specimens there are either 2 or 3 of these, usually flanked by I slender tooth on each side (Fig. 2A), but in specimen 8 from Jennycliff there are 3 tubercular teeth only. Further differences exist in the number of teeth on the inner edge of the poison claw, $\mathrm{I}_{4}$ in north-western, from 7 to 15 in southern specimens: the number of coxal pores on the anal leg, 4-5 in Blower's specimens, $2-5$ in mine, and finally in the degree of development of the claw on the anal leg, which is small in some southern specimens as in north-western ones (Fig. 2C), well developed in others (Fig. 2B).
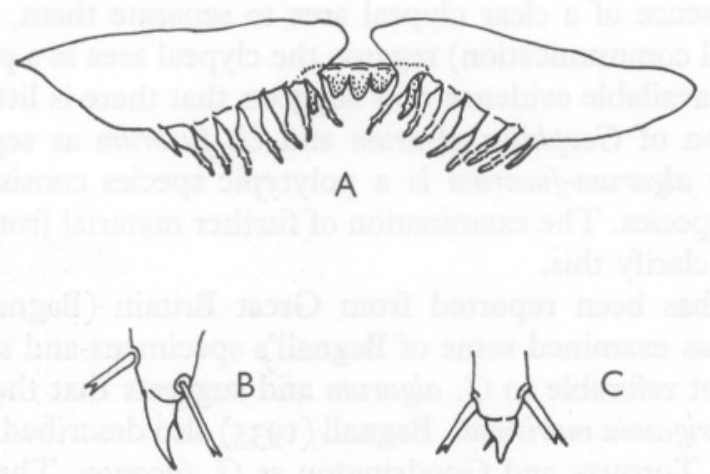

Fig. 2. Geophilus fucorum seurati. A, Labrum of male from Wembury Bay, Plymouth, mid part of labrum stippled; B, terminal claw of anal leg of female from Whitstable, Kent; c, terminal claw of anal leg of female from Jennycliff Bay, Plymouth.

TABLE 5. THE MAIN TAXONOMIC CHARACTERS DISTINGUISHING FORMS OF GEOPHILUS ALGARUM AND GEOPHILUS FUCORUM

\begin{tabular}{|c|c|c|c|}
\hline Character & G. algarum algarum & G. fucorum fucorum & G. fucorum seurati \\
\hline Labral teeth & 2 & $5-7$ & $3-5$ \\
\hline Clear clypeal area & Present & Absent & Absent \\
\hline Prehensorial teeth & $8-12$ & I2-I4 & $7-15$ \\
\hline Coxal pores & $\begin{array}{l}3 \text { ventral + I dorsal } \\
\text { (var. decipiens no } \\
\text { dorsal pore) }\end{array}$ & $\begin{array}{l}2+\mathrm{I} \text { isolated pore, } \\
\text { All ventral }\end{array}$ & $2-5$ all ventral \\
\hline Claw of anal leg & Well developed & Rudimentary & Small to large \\
\hline
\end{tabular}

The main characters separating G. algarum algarum from the Atlantic coast of France and G. fucorum fucorum from the French Mediterranean are shown in Table 5. They are taken from Brölemann (1930). In the third column, the characters of British G. fucorum seurati are shown. Inspection of this table shows that several characters bridge, or are intermediate between, those separating the two species. Thus some of the south coast G. fucorum seurati 
have only one more labral tooth than G. algarum, and forms with only the two central teeth tuberculate may easily be confused with $G$. algarum since the slender flanking teeth are inconspicuous. The range in number of teeth on the inner edge of the poison claw of British specimens spans the variation found between the two species, and the arrangement of pores on the coxae of the anal legs in some is as in Brölemann's G. fucorum seurati, in others as in his G. algarum var. decipiens, viz. three ventral pores lying along the border of the last sternite. Again, in some British specimens the claw is well developed as in G. algarum, in others it is reduced and approaches the rudimentary state found in $G$. fucorum fucorum.

Thus, apart from the number of labral teeth, which does not now appear to be a good distinguishing feature for the two species, there remains only the presence or absence of a clear clypeal area to separate them, and Dr E. H. Eason (personal communication) regards the clypeal area as a poor taxonomic character. The available evidence now suggests that there is little justification for the retention of Geophilus algarum and G. fucorum as separate species. More probably algarum-fucorum is a polytypic species consisting of highly individual subspecies. The examination of further material from the coasts of France should clarify this.

G. algarum has been reported from Great Britain (Bagnall, I9I7), but Eason (I96I) has examined some of Bagnall's specimens and states that they are certainly not referable to G. algarum and suggests that they are stadium adolescens I Strigamia maritima. Bagnall (1935) also described two immature Geophilus from Torquay and Goodrington as G. fucorum. The median piece of the labrum bore 5 teeth and the anal coxae each carried 3 pores. It seems probable that these specimens were G. fucorum seurati.

\section{DISCUSSION}

Of the six species of geophilomorph centipedes reported from the sea shore in the Plymouth area, Clinopodes linearis is probably a stray from some terrestrial habitat. Necrophloeophagus longicornis, on the other hand, though normally a terrestrial species, appears to be fairly common on British beaches, and it is possible that it has become established on some of them. Geophilus fucorum seurati, Strigamia maritima and Hydroschendyla submarina are found only in the littoral zone: the first species appears to occur only around HWM, but $S$. maritima, though it appears to occur no lower than MHWN at Plymouth, has been found down to mid-tide level in the Isle of Man (Blower, I957). Hydroschendyla replaces S. maritima at about MHWN level, and is found down to about mid-tide level, though in Jersey it has been found 'close to the water mark of very low spring tides where it could not be exposed for more than two days a fortnight' (D'Arcy Thompson, I889).

Strigamia maritima and Hydroschendyla submarina present a contrast in the 
methods by which they maintain themselves on the shore. S.maritima, though capable of withstanding immersion in the intermoult post-larval stages, lays permeable eggs and is probably unable to withstand immersion while moulting: for these reasons it is forced to migrate up the shore at the times of moulting and egg-laying. Hydroschendyla, on the other hand, has adapted physiologically, and does not migrate up the shore at these times, laying impermeable eggs and moulting in the intertidal zone. It seems likely that some specimens may avoid immersion by taking refuge in small air pockets in rock crevices, but to what extent they do this is not known.

Field observations suggest that populations of S. maritima and H. submarina at Plymouth are more dense than are terrestrial centipede populations. It has already been suggested that this may in part be due to the absence of large predators on the upper shore, and the absence of parasites due to the unsuitability of the external environment for the development of their intermediate stages (Lewis, I96I $a$ ). Strigamia from the top of the shore commonly carry hypopi (resting stages) of tyroglyphid mites, but these are invariably absent from Hydroschendyla which occurs lower down the shore. This may again be due to the unsuitability of the littoral zone for the development of the adult mite, or may be due to the direct effect of frequent immersion in sea water on the hypopi. Further factors favouring littoral centipede populations may be the abundance of food, and the ameliorating effect of the sea on the climate of the littoral zone. The latter factor may account for the presence of Schendyla peyerimhoffi and Geophilus pusillifrater Verhoeff on shores in the south of England (Lewis, 196I $b$ ).

The varied nature of the coast tends to break up littoral centipede species into a number of more or less isolated populations such as are expected to favour genetic divergence. Such genetic difference is probably reflected in the differences found between the various populations of Strigamia maritima and between populations of Geophilus algarum and G. fucorum.

I wish to thank Prof. J. E. Smith, F.R.S., Mr J. Gordon Blower and Prof. J. L. Cloudsley-Thompson for their helpful comments on the manuscript, Dr A. Joyner and DrW. Ballantine for giving me specimens collected by them, and Prof. G. E. Newell for allowing me to examine the centipedes which he collected at Wembury Bay.

My thanks are also due to the Director and Staff of the Plymouth Laboratory for providing excellent research facilities, and to London University for allowing me to occupy the University Table at Plymouth.

\section{SUMMARY}

Six species of geophilomorph centipede are reported from the littoral zone in the Plymouth area, and in two cases, where they differ from previous descriptions, the significance of these differences is discussed. It is suggested that the 
various British and French populations of Geophilus algarum and Geophilus fucorum may be subspecies of one polytypic species.

It is shown that Strigamia maritima and Hydroschendyla submarina differ in the way in which they have adapted to life on the shore. The former lays permeable eggs and migrates out of the littoral zone to lay them and to moult, the latter lays impermeable eggs and moults in the intertidal zone. Information on the prey of $S$. maritima at Plymouth is given.

The variations between some populations of littoral centipedes is discussed and possible reasons for the high density of populations of $S$. maritima and H. submarina are given.

\section{REFERENCES}

Bagnall, R. S., I9I7. On some Lancashire and Cheshire Myriapods new to the British Fauna, with comments on halophilous species. Lancs. Chesh. Nat., Vol. Io, pp. 104-9.

- 1935. Notes on British chilopods (centipedes). I. Ann. mag. Nat. Hist., Ser. Io, Vol. 15, pp. 473-9.

Bassindale, R. \& Barrett, J. H., I957. The Dale Fort marine fauna. Proc. Bristol Nat. Soc., Vol. 29, pp. 227-328.

BLoweR, J. G., I955a. Yorkshire centipedes. Naturalist, Lond., I955, pp. 137-46.

- 1955b. Millipedes and centipedes as soil animals. In Soil Zoology. Kevan, D. K. McE. (ed.). London.

1957. Feeding habits of a marine centipede. Nature, Lond., Vol. I80, p. 560. I961. On some new and little known British centipedes. Ann. mag. Nat. Hist., Ser. 13, Vol. 4, pp. 183-7.

BRölemanN, H. W., 1930. Eléments d'une faune des Myriapodes de France: Chilopodes. Faune de France, No. 25.

Cloudsley-Thompson, J. L., I948. Hydroschendyla submarina (Grube) in Yorkshire with a historical review of the marine Myriapoda. Naturalist, Lond. (1948), pp. I49-52.

— I95I. Supplementary notes on Myriapoda. Naturalist, Lond. (I95I), pp. 16-I7.

Eason, E. H., 1957. Chilopoda and Diplopoda from Caernarvonshire. Proc. zool. Soc. Lond., Vol. I29, pp. 273-91.

- I96r. On the synonomy of some British centipedes. Ann. mag. Nat. Hist., Ser. 13, Vol. 4, pp. 385-91.

JACKSON, A. R., I916. On some arthropods observed in 1915. II. Myriapoda. Lancs. Chesh. Nat., Vol. 8, p. 39r.

LewIS, J. G. E., I96I $a$. The life history and ecology of the littoral centipede Strigamia (= Scolioplanes) maritima (Leach). Proc. zool. Soc. Lond., Vol. 137, pp. 22 I-48.

- $196 \mathrm{I} b$. On Schendyla peyerimhoffi Brölemann and Ribaut and Geophilus pusillifrater Verhoeff, two geophilomorph centipedes new to the British Isles. Ann.mag. Nat. Hist., Ser. 13, Vol. 4, pp. 393-9.

Marine Biological Association, 1957. Plymouth Marine Fauna. 3rd edition. Plymouth.

Morton, J. E., 1954. The crevice fauna of the upper intertidal zone at Wembury. f. mar. Biol. Ass. U.K., Vol. 33, pp. 297-3I2.

PARFITt, E., 1866. Rediscovery of Geophilus maritimus of Leach. Zoologist, Vol. 24, p. 7.

Pocock, R. I., I899. A marine millipede. Nature, Lond., Vol. 4I, pp. I76-7.

- 1903. Myriapoda. Victoria Co. Hist., Essex, Vol. I, pp. 193-4.

T(hompson), D’A. W., I889. A marine millipede. Nature, Lond., Vol. 4I, p. 104. 